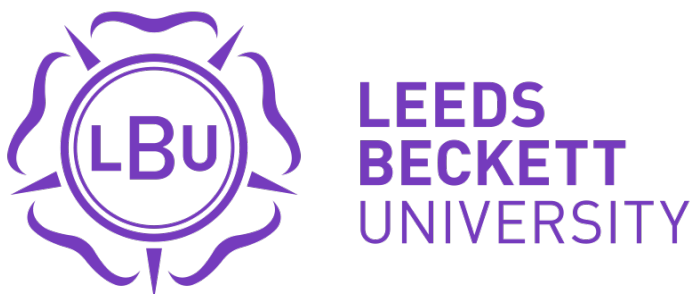

\section{Citation:}

Langan, $M$ and Price, S (2020) Imperialisms Past and Present in EU Economic Relations with North Africa. Interventions. pp. 1-19. ISSN 1369-801X DOI: https://doi.org/10.1080/1369801X.2020.1718540

Link to Leeds Beckett Repository record:

https://eprints.leedsbeckett.ac.uk/id/eprint/6528/

Document Version:

Article (Accepted Version)

The aim of the Leeds Beckett Repository is to provide open access to our research, as required by funder policies and permitted by publishers and copyright law.

The Leeds Beckett repository holds a wide range of publications, each of which has been checked for copyright and the relevant embargo period has been applied by the Research Services team.

We operate on a standard take-down policy. If you are the author or publisher of an output and you would like it removed from the repository, please contact us and we will investigate on a case-by-case basis.

Each thesis in the repository has been cleared where necessary by the author for third party copyright. If you would like a thesis to be removed from the repository or believe there is an issue with copyright, please contact us on openaccess@leedsbeckett.ac.uk and we will investigate on a case-by-case basis. 


\title{
Imperialisms Past and Present in EU Economic Relations with North Africa:
}

\section{Assessing the Deep and Comprehensive Free Trade Agreements}

\begin{abstract}
The EU is actively pursuing Deep and Comprehensive Free Trade Agreements (DCFTAs) as part of its trade and aid relations with former colonies in North Africa. Utilising the discourse of propoor business growth and win-win free trade, the EU insists that North African countries must acquiesce to DCFTA liberalisation to achieve sustainable development. This article critiques the paternalism of EU actors amidst their focus on completing these controversial DCFTAs. Drawing upon Nkrumah's and Fanon's articulation of the concept of neo-colonialism, it argues that the EU is cementing colonial-style patterns of production via iniquitous trade and aid arrangements. Moreover, the article illustrates that EU elites in their justification of the DCFTAs are replicating the colonial-era discourse surrounding Eurafrica and the alleged economic 'complementarity' and inevitable 'interdependence' of the European and African continents: An amnesiac Europe thus simultaneously draws upon European colonial imaginaries in the justification of neo-colonial DCFTAs while downplaying, and forgetting, the regressive legacies of colonial trade relations. The article also demonstrates how certain North African campaigners are already drawing attention to the neo-colonial contours of the DCFTAs in order to delegitimise these free trade vehicles vis-à-vis North African and European public opinion.
\end{abstract}

\section{Keywords:}

trade liberalisation; Eurafrica; neo-colonialism; interdependence; DCFTAs; development 


\section{Introduction}

The European Union (EU) is actively pursuing Deep and Comprehensive Free Trade Agreements (DCFTAs) in the Arab Mediterranean. Morocco, Tunisia and Egypt have been identified as key partners with whom the European Commission wishes to conclude DCFTAs as part of an eventual African-European bi-continental free trade zone (Chadwick 2018). The DCFTAs will not only ensure that EU-North African trade remains compliant with World Trade Organisation (WTO) regulations regarding mutual tariff liberalisation. But, they will ostensibly provide a necessary stimulus to Arab Mediterranean economies. In this sense, the DCFTAs are viewed as a genuine opportunity for win-win co-operation. And, by assisting 'weaker' developing countries through DCFTAs, the EU presents itself as a benevolent partner for sustainable development. This aligns with Nicolaidis (2015) and her conceptual focus on EU strategies of 'amnesia', 'redirection', and 'atonement' - as explored by Pace and Roccu (this special issue) in the introduction to this special issue.

Despite the EU's normative discourse, however, there is mounting evidence and adjacent civil society concerns that the DCFTAs will not provide a genuine opportunity for win-win economic growth. In particular, there is concern that the EU is utilising the DCFTAs as a device to lock-in poorer countries into colonial-style patterns of raw material exports married to importation of higher-value, processed commodities (see Swearingen 1988 for a comprehensive account of colonial economics in the region). Analysis of the likely empirical implications of DCFTAs already points to the dangers of premature trade liberalisation for emerging sectors in Morocco, Tunisia and Egypt (GPA and Solidar 2013).

Accordingly, the article examines the DCFTAs and their likely impact for the Arab Mediterranean in terms of Europe's imperial past and its neo-colonial present. It explores how Europe simultaneously draws upon a colonial Eurafrican discourse of economic 
'complementarity' and 'interdependence' to justify DCFTAs, while at the same time downplaying the implications of neo-colonial ties (also see Pace and Roccu [2019]) in this special issue for a discussion of Eurafrica as a concept). In this process, the article engages contemporary literature that highlights the imperial contours of EU trade external agendas, notably Zielonka (2006); Del Sarto (2016); Nicolaidis (2015); Pasture (2018); and Thorpe (2018). Crucially, however, the article emphasises that it is necessary to re-engage writers from the Global South whose works date back to the onset of neo-colonialism in the 1960s. Namely, it is vital to re-engage the work of Kwame Nkrumah (1965) and Frantz Fanon (1961) with regards to the practical strategies of the European project in its construction of the neo-colonial present. By doing so, it becomes possible to more fully understand - and to challenge - EU neo-colonialism as embodied in the contemporary DCFTA agenda.

The discussion is structured as follows. The first section examines the theoretical literature pertaining to the EU's imperial past and neo-colonial present. The second section then unpacks the DCFTA agenda in terms of its imperial legacies and neo-colonial contours. The third section then highlights the likely empirical consequences of DCFTAs for vital sectors in the Arab Mediterranean. The conclusion then restates the dubious ethical consequences of Europe's amnesiac ‘forgetting' of imperial histories and downplaying of a neo-colonial present.

\section{Theorising Imperialism Past and Present in EU External Trade and Economic Agendas}

The European Commission $(2005 ; 2006 ; 2019 a ; 2019 b ; 2018)$ regularly invokes a progressive 'development' discourse in its trade relations. European officials state that free trade between EU member states and developing countries will lead to gains for all parties. Namely, the EU will gain access to lucrative emerging markets - such as telecommunications - and secure long- 
term access to vital agricultural and mineral raw commodities. In return, developing countries will gain access to foreign capital, European consumer markets, and potential Aid for Trade. Through win-win free trade deals, the EU can thus contribute to poverty reduction in the Global South. EU discourse in this fashion corroborates the analysis of Nicolaidis (2015) and her conceptual focus on 'atonement' as a chief strategy deployed by European officials in their dealings with former colonial possessions.

Interestingly, the EU's liberal trade discourse of economic complementarity, interdependence, and win-win trade co-operation is echoed within the scholarly liberal literature. Certain liberal scholars - such as Gruhn (1976) and Stevens and Kennan (2005) have historically maintained that the EU is slowly but surely inching towards a genuine interdependence in trade relations with developing countries. In so doing, such scholars broadly maintain that the European Commission is i. sincere in its policy pronouncements to 'do good' via enhanced trade linkages, and ii. is successfully realising a progressive model of trade relations that moves beyond colonial-era dependency (in which developing countries remained economically subordinate to the metropole as suppliers of raw materials and importers of higher-value consumables).

However, there is a critical theoretical tradition in the scholarly literature which convincingly illustrates how the EU is pursuing imperial and/or neo-colonial strategies in its economic dealings with the Global South. For instance, Galtung (1973), Hurt (2003), and Nunn and Price (2004) have historically demonstrated how EU trade policies entrench commercial prerogatives in Africa at the expense of the long-term growth of their poorer partners. In particular, there is evidence that the EU pursues trade liberalisation in the Global South for the benefit of European industry (which secures access to a foreign consumer base as well as to raw materials), despite the corollary that this stifles opportunities for developing countries to 
build their own competitive muscle. As a result there are accusations that the EU is effectively 'kicking-away-the-ladder' of development since infant industry collapses in developing countries upon import flooding of cheaper European wares precipitated upon the implementation of premature free trade agreements, to the detriment of local industrialisation and economic diversification (c.f. Chang 2002).

In the current era of DCFTAs, a number of contemporary critical writings have theorised how EU trade policies (among other policy instruments) perpetuate imperial and neocolonial forms of North-South relations. Del Sarto (2016), for instance, convincingly argues how the EU supports pliable local elites via aid as a means of maintaining colonial patterns of economic interaction. Salem (2019) in this special issue, and Zielonka (2006), meanwhile, theorise about the economic aspects of domination. In particular, Zielonka (2006) queries whether the EU can only maintain its own labour and environmental standards by imposing them onto partners within trade agreements. In a related vein, Nicolaidis (2015) claims that EU external agendas can be viewed in terms of the concept of imperial 'redirection'. This involves the EU's pursuit of internal deep integration, followed by the pursuit of external influence by the united European entity. Free trade agendas - such as the DCFTAs - can therefore usefully be interpreted (qua Nicolaidis) as part of European redirection strategies - by externally projecting Europe's collective power impulses.

Furthermore, contributions from Martin (1982), Hansen and Jonsson (2014), Pasture (2018) and Thorpe (2018) have illustrated how historical imperial discourse continues to inform EU external agendas. In particular, these authors have collectively pointed to the Eurafrican foundations of the European project and how the EU today makes claims as to the alleged economic ‘complementarity' and 'interdependence' of Europe and Africa, in alignment with Eurafrican colonial discourse popularised in the 1950s. As Martin (1982: 222) explains, the 
twin concepts of economic complementarity and interdependence between Europe and Africa formed, and today still form, cornerstones of an imperial Eurafrican vision.

However, while this critical European scholarship helps to correctly conceptualise EU imperial 'redirection' and to highlight Eurafrican legacies, it is vital to re-engage critical literature from the Global South. In particular, re-engagement with the classic works of intellectuals such as Kwame Nkrumah (1965), Frantz Fanon (1961), as well as Sekou Touré (1962) - among others - can rebalance our contemporary analyses of Europe's dealings with developing countries. Usefully, Nkrumah's unpacking of neo-colonialism in Africa can help us to understand the EU's collective pursuit of free trade deals such as the DCFTAs. Nkrumah (1965: ix) usefully defined the phenomenon in the following terms:

The essence of neo-colonialism is that the state which is subject to it is, in theory, independent and has all the outward trappings of international sovereignty. In reality, its economic system and thus its political policy is directed by the outside.

And as Pace and Roccu (2019:2) in this special issue illustrate, this critique of neocolonialism can also be found within Fanon's work, which warned that without full economic and political sovereignty, decolonisation would be nothing more than a surface shift for the new formally independent states. With regards to European external powers, meanwhile, Nkrumah (1965) explicitly warned his African contemporaries that the then European Economic Community (EEC) would seek to achieve a neo-colonial dominance over erstwhile colonies. Namely, that the EEC would cajole de jure independent states in Africa into 'Association' agreements that would necessitate prematurely open markets and continued economic dependence. Nkrumah (1965) - and his pan-African ally Sekou Touré (1962) - warned here that the unconditional opening of markets as part of Association between the European 
Economic Community (EEC) and African states would foreclose the possibility of industrial diversification in advance, leading to economic and political dependency.

In Touré's (1962: 141) memorable allusion to a biblical verse, African countries would remain "hewers of wood and drawers of water" if Association enabled the EEC to have unfettered access to African markets. The influx of cheap European imports would decimate infant industry and would ensure that African countries would remain economically dependent on raw material exports to the EEC metropole. Nkrumah and Touré therefore warned Francophone African states against the perpetuation of Association under the Yaoundé Conventions (1963-1975). Indeed, Association had already begun under the 1957 Treaty of Rome without any consent from then colonies, and were controversially renewed under Yaoundé. As Segal (1964: 87) succinctly remarks in his contemporaneous account:

President Nkrumah's objections to associated status are both economic and ideological. According to him, associated states will perpetuate neo-colonialism and provide a fundamental obstacle to the achievement of African political and economic unity, which is the sole means whereby African states can overcome their lack of development.

Moreover, and with parallels to Nicolaidis (2015), Nkrumah also warned that EEC aid monies would be used as a lubricant to secure the acquiescence of African leaders to Association and to trade agreements that stifled long-term economic growth in the continent. In clear terms he laid out the possible usages of aid monies to subvert empirical state sovereignty in newly independent African countries:

Control over government policy in the neo-colonial state may be secured by payments towards the costs of running the state, by the provision of civil servants in positions where they can dictate policy, and by monetary control over foreign 
exchange through the imposition of a banking system controlled by the imperialist power (1965: ix).

The noxious marriage of aid monies to disadvantageous trade deals was, meanwhile, reiterated by Fanon. Having established links with Nkrumah during his time in Ghana, Fanon (1961: 76) wrote in similar terms of the dangers of neo-colonialism, aid money, and asymmetric trade:

The former dominated country becomes an economically dependent country. The ex-colonial power, which has kept intact and sometimes even reinforced its colonialist trade channels agrees to provision the budget of the independent national by small [aid] injections.

Crucially, however, both Nkrumah and Fanon emphasised how African actors were not passive recipients of neo-colonial intrusions by European powers in the Cold War context. Nkrumah (1965: 33), in particular, emphasised that certain African elites would willingly embrace trade and aid overtures from foreign powers in order to lubricate their own domestic patronage networks. Rather than seek to break from colonial patterns of trade and economic exchange, some African leaderships would work with former colonial centres to lever in aid monies and to gain foreign support for their rule (oftentimes including military assistance) (ibid). Despite the fact that neo-colonial trade relations would retard efforts for poverty reduction and industrialisation, some pliable African elites would sacrifice their citizenries' longer-term economic wellbeing for their immediate power purposes. Fanon, meanwhile, explained this same phenomenon in terms of African leaderships who would reject the austerity politics likely necessitated in the short term from a break from colonial trade ties. Such leaders would choose the path of least resistance by allying themselves to foreign powers:

Other countries of the Third World refuse to undergo this ordeal and agree to get over it by accepting the conditions of the former guardian power. These countries 
use their strategic position--a position which accords them privileged treatment in the struggle between the two blocs -- to conclude treaties and give undertakings. The former dominated country becomes an economically dependent country. (Fanon 1961: 76).

For both Nkrumah and Fanon, therefore, strategies for overcoming neo-colonial incursions, and temptations, would be found within pan-African alliances. Only through the eventual creation of a Union of African States would African leaderships enjoy the political and economic clout to meaningfully diversify economic systems away from colonial patterns of trade, and to do away with corrupting aid dependence (Langan 2017: 219-220).

Interestingly for the current consideration of DCFTAs, Nkrumah also condemned what he deemed as artificial demarcations between North Africa and sub-Saharan Africa (Langan 2017: 220). As part of this pan-African sensibility, he famously formed a political relationship with Egypt's Gamel Abdul Nasser, later marrying an Egyptian national. His Casablanca Group of States (African states which favoured a rapid move to unity within a federal state) in the 1960s also found much political support from the Moroccan monarchy (hence Casablanca). With the warnings about neo-colonial forms of North-South relations in mind it is now relevant to explore the EU's pursuit of DCFTAs in the Arab Mediterranean.

\section{Imperialisms Past and Present in Europe's DCFTAs in the Arab Mediterranean}

The EU's DCFTA agenda has been launched in the context of Association Agreements with each of the targeted partners in the Arab Mediterranean. The Association Agreements - similar to the Cotonou Agreement signed between the EU and African, Caribbean and Pacific (ACP) countries - lay out a framework for political, economic and social interaction between Europe and its partners. In the case of Tunisia, Morocco and Egypt, their Association Agreements lay the bedrock for the ongoing negotiations towards free trade deals embodied within the 
DCFTAs. Importantly - and with echoes of Nkrumah (1965) and his concept of neo-colonialism - these Association Agreements also lay the conditions for the flow of oftentimes substantial aid monies from Brussels to the signatories. This frequently has taken the form of budget support - namely financial transfers direct to central governments- as warned against by Fanon in terms of the foreign provisioning of African budgets (c.f. Langan 2015a). Simultaneously, therefore, North African governments have entered into controversial DCFTA negotiations while being funded in no small measure by EU aid monies.

It is important, however, to contextualise the DCFTAs in the Arab Mediterranean in terms of a wider African policy pursued by the EU. Since the publication of the European Commission's (1996) Green Paper on the Future of EU Relations with the African, Caribbean and Pacific $(A C P)$ Countries, the European Commission has made abundantly clear that its intention is to forge ahead with free trade deals with former colonies in the continent. Embracing a strategy of amnesia (Nicolaidis 2015), the Green Paper (1996: 11) declares that the "colonial period and the post-colonial period" are behind us, and that therefore the parties are able to express themselves "less ambiguously". The Green Paper also goes on to claim that 'reciprocal' free trade between Europe and developing countries can enable all to flourish within competitive global markets.

In the context of the ACP-EU Cotonou Agreement (2000: 26) itself, this progressive discourse is restated, with the text claiming that EPAs can help ACP countries to realise "smooth and gradual integration" into globalised markets. In particular, market-opening under free trade deals is seen as a vital stimulus for private sector activities, and as a means of disciplining less competitive industries to naturally wind-down upon liberalisation. Again, with emphasis on aid monies, the Cotonou Agreement promises that finances will be made available to ensure ACP countries' fair entry into globalised markets. Thus, the EU has delivered 
substantial sums to ACP countries in the form of both budget support (to national governments) as well as Aid for Trade (AfT) delivered through the European Development Fund (EDF). This has attracted condemnation in relation to the concept of neo-colonialism, with such aid monies being seen as tied to the EU's controversial pursuit of EPA free trade deals (Langan 2015a; 2017).

It is in this wider African context that we must position the DCFTA economic agenda. The European Commission, to a large extent, is seeking to replicate its free trade orientation towards the ACP countries in its dealings with North Africa (since the ACP bloc includes only sub-Saharan African states and not those of the Arab Mediterranean). This is especially apparent with the close of the Cotonou Agreement in 2020. The European Commission is increasingly emphasising the need to have a relationship with the African Union [AU] (including its North African constituents) amidst the planned African Continental Free Trade Area (AfCFTA), rather than with the ACP bloc. In fact, the ACP group is sometimes seen as an unsightly relic of the colonial past (again corroborating a politics of amnesia as outlined by Nicolaidis)

Accordingly, the DCFTAs are not only building blocks towards an eventual EuroMediterranean Free Trade Agreement (EMFTA) as anticipated as far back as the 1995 Barcelona Declaration. In the context of EU-AU relations, the DCFTAs are in fact building blocks towards a Eurafrican free trade zone. This was recently confirmed within the final State of the Union address of President Juncker of the European Commission. He explained in direct terms that the EU planned to 'develop the numerous trade agreements between African and EU countries into a continental free-trade agreement, an economic partnership between equal partners' (Chadwick 2018). DCFTAs would thus form significant first-phase components (alongside EPAs in sub-Saharan Africa) of a future projected bi-continental free trade zone. 
Crucially in terms of imperial legacies, however, the Eurafrican implications of the DCFTAs not only find expression in terms of the future ambition of the EU to use these as a stepping-stone to a wider Euro-African free trade area. Rather, the EU's contemporary discursive reliance upon narratives relating to Eurafrican concepts of economic complementarity and interdependence heavily draws upon historical imperial legacies that are regularly forgotten in the pursuit of free trade deals (as Nicolaidis rightly terms - a strategy of amnesia). As recently as March 2018, the then Trade Commissioner, Cecilia Malmström, reaffirmed Europe's rhetorical commitment to the core concepts of complementarity and interdependence as a means of justifying the DCFTAs, the EMFTA, and eventually a EuroAfrican free trade zone:

There are some who think trade is a competition. But we know it is not a zerosum game. Our products feed into each other's value chains; they are vital to each other's economies and support each other's societies (European Commission, 2018, emphasis added).

This echoes the language of her predecessors, especially Peter Mandelson, who also justified the pursuit of DCFTAs in terms of seeking "a strengthened partnership between close and interdependent neighbours" (European Commission 2007; emphasis added). This conceptual focus on interdependence and complementary is unsurprising given the fact that the European Commission has long stressed the centrality of trade ties as part of a EuroMediterranean 'alliance'. Even before the Barcelona Declaration in 1995 which launched negotiations for the DCFTAs, the European Commission (1993) made clear that a "EuroMaghreb" partnership would seek to "anchor" the Arab Mediterranean to the European continent, and that this alliance would explicitly utilise trade as a foundation: 'trade is obviously a crucial area, both for economic development and interdependence. It is the very symbol of 
the Maghreb's and the Community's desire for partnership' (emphasis added). This is corroborated by Morillas and Soleri i Lecha (2017: 4) who explain that the foundations of the Euro-Mediterranean partnership focused on interdependence as a conceptual anchor:

the Mediterranean was a challenge. From that point of view, it was inevitable and even natural to intensify cooperation between the EU and the Southern and Eastern Mediterranean countries. The magic word was "interdependence". The European Commission (1994: 2), for instance, listed environment, energy, migration, trade and investment as "areas of Euro-Mediterranean interdependence" and considered that Europeans had "a vital interest in helping Mediterranean countries meet the challenges they face".

Through such Eurafrican discursive strategies, Europe is represented as a 'force for good', thus downplaying any accusations that it is acting as a neo-colonial power through imposition of premature trade liberalisation (with the concomitant decline of industry in African states and the lock-in of colonial patterns of raw material export to the metropole). With parallels to much academic literature on 'normative power Europe', the EU is thus held as a benevolent contributor to development (Pace 2007: 1045).

Furthermore, the EU's discursive focus on economic interdependence vis-à-vis the Arab Mediterranean has recently evolved to include security concerns in light of $9 / 11$, the Arab Spring and the migration 'crisis'. Trade politics thus remain at the fore of the relationship with free trade deals now increasingly viewed as important for security through the potential creation of jobs for young men. Economic interdependence therefore becomes part of tackling what Federica Mogherini regularly refers to as the "root causes of poverty and irregular migration" (cited in Chadwick 2017). Crucially this trade-security nexus itself draws upon imperial discourse and legacies - re-articulating imperial Eurafrican narratives that while the 
Arab Mediterranean is a valuable economic 'complement' to Europe, that nevertheless it is a zone of potential danger that must be controlled, or at least contained. As Cebeci and Schumacher (2017: 12) remark, this trade-security discourse:

inevitably brings about the depiction of the target societies as defected and weak, unable to take care of themselves (i.e., pursue reforms or resolve conflicts) and thus in need of the EU's help. One is reminded of the colonial logic - the mission civilisatrice.

An imperial sensibility relating to Europe's alleged cultural superiority thus pervades EU discourse even in economic matters. Eurafrican imperial mentalities are therefore clearly with us in the neo-colonial economic present, in terms of discourse impacting upon EU mindsets in the approach to trade ties with North African countries. Crucially, however, the imperial past itself is never fully acknowledged, within a politics of amnesia (see also Sierp in this special issue).

In addition to the amnestic utilisation of imperial discourse in the downplaying of neocolonial economic realities, it is also important to acknowledge coinciding EU discursive strategies of "atonement" and "redirection" (Nicolaidis 2015). In terms of atonement, the European Commission (2018b) insists that the DCFTAs represent a poverty alleviation boon in alignment with the UN Sustainable Development Goals (SDGs). Brushing aside North African civil society and trade union concerns, EU officials maintain that trade liberalisation is a necessity, not only in terms of compliance with WTO regulations, but for providing the means for pro-poor economic growth. Moreover, the European Commission insists that North African countries' will be able to improve their social and environmental standing by conforming to EU production norms embodied in the acquis communitaire. The diffusion of EU norms - for example in terms of the restricted use of pesticides in vegetable production - will not only 
benefit European consumers (who eventually eat imported produce from North Africa) - but will improve both social and ecological conditions in the Associated partners. In keeping with the concept of "redirection", therefore, the EU projects its power prerogatives onto its neighbours - while discursively eschewing accusations of neo-colonialism via progressive narratives of sustainable development. EU trade policies - especially the DCFTAs -are therefore viewed as a legitimate and desirable contribution to a just form of North-South relations in keeping with the UN SDG agenda.

Despite the EU's discursive strategies, however, there has been substantial negative reaction within the Arab Mediterranean with regards to the DCFTAs. With echoes of Nkrumah (1965) and Fanon (1961), civil society movements and trade unions have voiced vociferous concerns that premature trade liberalisation will perpetuate neo-colonial forms of economic ties by hampering industrialisation and economic diversification. Free trade deals may protect Arab exporters' access to EU markets in primary commodities such as vegetables and unprocessed agricultural goods. However, the conclusion of the DCFTAs will ensure unfettered access to North African markets for European producers of manufactured goods and processed agricultural commodities such as tomato paste and poultry. Accordingly, local industry and agro-processing units will likely close upon the import flooding of cheaper European wares. Accordingly, North African states will - to borrow Toure's (1962) phrase - remain as "hewers of wood and drawers of water" - unable to diversify away from colonial patterns of production within neo-colonial North-South trade ties. The section below therefore examines the likely impact of the DCFTAs for poorer citizenries in the Arab Mediterranean.

\section{Trade Liberalisation under DCFTAs through the lens of Neo-Colonialism}


Despite the EU's normative discursive focus on economic interdependence, trade complementarity, and poverty reduction in the Arab Mediterranean, it is immediately clear from the structure of the economic relationship that there is an inherent imbalance between the parties, perpetuating colonial-era trade asymmetries (see Swearingen 1988 for an account of colonial economics). Premature trade liberalisation under DCFTAs, in this context, will exacerbate existing inequalities based upon North African states' subordinate economic position. As Martin convincingly argues, the DCFTAs (and EMFTA) will not even lead to 'reciprocal' liberalisation conducive to Arab Mediterranean exports due to the EU's protectionist policies. The discourse of free trade inherent within DCFTAs is thus somewhat fraudulent, since only the North African partners themselves are meaningfully opening their markets under the deals:

Insomuch as EMFTAs [DCFTAs] are not truly reciprocal, because there is no corresponding liberalisation of agricultural exports to the EU in exchange for opening up Mediterranean Partner Countries (MPC) markets to European industrial products, the best that can be said is that EMFTAs are potentially damaging to the MPC economies and will do nothing to alleviate, let alone improve, their social situation (cited in Langan 2015b: 1834).

Moreover, in relation to Zielonka's (2006) discussion of the acquis communitaire, small and medium sized enterprises (SMEs) in the Arab Mediterranean will be compelled into adherence to the strict environmental and health standards of the EU within DCFTAs. This will be a barrier to upgrading and diversification into agro-processing, given the high costs involved with such conformity. This is consistent with Nkrumah's (1965) warnings about neocolonialism (as well as Nicolaidis's warnings of EU redirection strategies) in terms of the 
impact of free trade arrangements that lock-in North African states into primary agricultural production. Under DCFTAs both tariff and non-tariff barriers (NTBs) will remain in place in relation to North Africa's processed agricultural goods (and manufactured wares) which might otherwise challenge European counterparts.

Moreover, recent trade statistics demonstrate that colonial patterns of trade prevail. Tunisia and Morocco, for instance, remain highly dependent upon exports to Europe, as per colonial times. The EU is the largest trading partner for both Morocco and Tunisia, accounting respectively for 59.4\% and 64\% of their trade in 2017 (European Commission 2019a, 2019b). In that year, $64.6 \%$ of Morocco's and $78.5 \%$ of Tunisia's exports went to the EU, and $56.5 \%$ of Morocco's and 54.3\% of Tunisia's imports came from the EU (European Commission 2019a, 2019b). The composition of exports to the EU from both Morocco and Tunisia is very similar, being predominantly agricultural products, as well as textiles and clothing, and machinery and transport equipment. The exports from the EU are similarly dominated by machinery and transport equipment, fuels, metals and minerals, agricultural products, textiles and clothing. There is also a two-way trade in services between the parties.

Crucially, however, the imbalance between the blocs is stark in relation to levels of trade dependency. While the EU is the primary market for both Morocco and Tunisia, both states hold relatively minor positions in the ranking of EU trade: Morocco is the EU's $22^{\text {nd }}$ largest trading partner and accounts for a mere $1 \%$ of the EU's total trade (European Commission 2019a). Tunisia is the EU's $34^{\text {th }}$ largest trading partner and accounts for a mere 0.6\% of the EU's total trade (European Commission 2019b). This imbalance in relative dependence underpins the EU's power to leverage its interests and dictate the terms of engagement vis-à-vis DCFTAs, reflecting Nkrumah's (1965), and more recently Zielonka's (2015), analysis of economic dominance. 
Specifically, the existing trade imbalance is currently being leveraged by the European Commission in a number of ways. First, in the asymmetry of trade liberalisation already undertaken. This has seen the EU continue to protect its agricultural sector from North African imports and subsidise European producers through the Common Agricultural Policy (CAP) while pursuing liberalisation across African countries (Djafari 2018). This is in keeping with the predictions made by Nkrumah (1965) and Touré (1963) about the then EEC seeking to open up the markets of the former colonies for European producers, denying local counterparts the opportunity to protect their nascent industries and expand, within a neo-colonial form of trade relations. The EU's economic dominance is also reflected in the terms of how the EU has only offered to increase export quotas to its markets in return for the full liberalisation of key sectors in Morocco and Tunisia. Second, the dominance of the EU is evident in the speed in which it is pursuing trade liberalisation. In spite of resistance from civil society and North African states' interests, the EU has been able to limit the proposed transition period to just ten years, forcing a rapid transition for the DCFTA signatories and their productive sectors. Djafari (2018) argues that 'the complexity of the DCFTA is incompatible with the ground realities' particularly in relation to the wholescale adoption of EU norms and standards.

Also corroborating the analysis of Nkrumah and Fanon, the European Commission has utilised aid monies via budget support modalities as a means of exerting a neo-colonial form of pressure (and incentive) vis-à-vis North African elites. In Tunisia, the European Commission allocated $€ 68$ million for 'economic recovery' in 2012 . This occurred only one week after the Tunisian government had acquiesced to a so-called 'Privileged Partnership' which locked-in this North African state to further liberalisation commitments in alignment with the proposed EMFTA (Langan 2015a: 108). This is despite the likely consequences of DCFTAs and the EMFTA itself for infant industry in the country. 
Usefully War on Want explain here that the DCFTAs/ EMFTA would lead to the near total collapse of key manufacturing industries in the Arab Mediterannean (ibid). This is corroborated by Zaafrane and Mahjoub who state that:

In...Tunisia, the portion of industrial production (approximately 10 per cent of GDP) threatened by the removal of imports on to tariffs from the EU has been estimated at 60 per cent of the total. Half of this output represents activities which are genuinely competitive in nature, while the remainder are protected and offer no real comparative advantage...[the evidence suggests that] one third of the industrial sector will have to be abandoned, while another third will have to be redeployed into the third sector (cited in Langan 2015b: 1834).

The Tunisian food, beverages and tobacco sectors would be particularly affected, with a fall of production anticipated at around 94.1\% (Langan 2015a: 108).

Moreover, this stark picture is also confirmed within the EU's own contracted Sustainability Impact Assessment which anticipates that Morocco and Tunisia will experience job losses of up to $8 \%$ of the total manufacturing workforce upon DCFTA implementation, and that industry will shrink by $64.1 \%$ and $65 \%$ in the two North African states respectively (Langan 2015b: 1835). The European Apparel and Textile Confederation (Euratex), meanwhile, welcomes the deals as a means of easing access to North African consumers, despite the deleterious impact for local infant industry (ibid).

While the European Commission has been able to operationalise its economic dominance to pursue neo-colonial trade ties under DCFTAs, it is important to note that the EU is not alone in concluding free trade deals in the region. Moroccan political elites, in particular, have demonstrated their openness to trade liberalisation since the mid-1990s, signing free trade 
agreements with 58 countries since then. Crucially, however, within this period its trade deficit with its partners has worsened, increasing fourfold over the last ten years and equalling nearly a quarter of GNP (Gardner 2017). This growth in the trade deficit is largely accounted for by its trade with the EU, which has been able to maximise its advantage to the detriment of key domestic industries (ibid). As per the original warnings of Nkrumah (1965), local sectors have not been able to cope with competition from European exports, which have taken a market share from domestic producers and caused a rapid rise in unemployment. The textile industry is one example, which has been one of the mainstays of the Moroccan economy and has been particularly affected, enduring a loss of nearly 30,000 jobs between 1999 and 2014 (Gardner 2017).

Alongside growing precarity in the labour force, issues of food security have also been intensified through trade liberalisation in the Arab Mediterranean - issues which would be exacerbated under DCFTAs and their emphasis on tariff liberalisation and foreign capital. Morocco, for instance, sought to address structural change in its agricultural sector through the Plan Maroc Vert. Indeed, Morocco has in recent times been recognised as a state that has made some significant progress in the reduction of food insecurity. However, the Plan Maroc Vert is based on the maximisation of production through large-scale farms and the diversification of production in small scale farms. It has centred on methods to channel external investment funds, including global venture capital and Private Agriculture Investment Firms, into Moroccan farming (for example, through large scale mechanisation, irrigation and soil fertilisation projects). It has also controversially given the opportunity for multinational corporations to promote the use and distribution of new seed variants. As a result, the agricultural sector and export trade has increased significantly, but this has brought with it wide-ranging criticisms of the prioritisation of the interests of large scale agricultural businesses over rural farmers living in poverty (Leon 2016). 
It is also important to note that the impacts of trade liberalisation in the Arab Mediterranean are varied, with women and youth often bearing the brunt of reforms such as those encompassed within the DCFTAs. While unemployment figures as an aggregate in North Africa have been showing a downward trend, the ILO (2016: online) stated that 'distress remains pervasive, particularly among women and youth. Northern Africa still exhibits the highest unemployment rate globally, at 12.1 per cent in 2015'. Moreover, North Africa has the highest regional youth unemployment rate in the world, 'at close to 30 per cent in $2015^{\text {' with }}$ high levels of young people not in education, employment or training (that is, NEETs: those Not in Education, Employment or Training) (ibid). The ILO further states that 'recent data shows that, among those aged 15-29, NEETs account for 32 per cent in Tunisia (reaching some 42 per cent of young women) and 40 per cent in Egypt (64 per cent of young women)' (ibid).

Interestingly, the existing impact of trade liberalisation upon women and youth in the region has prompted the EU to emphasise a discourse of 'inclusive growth' as part of the negotiations towards DCFTAs. This underpins and reinforces the rhetoric of win-win economic interdependence by positioning North African women and young people at the forefront of liberalisation strategies. This is corroborated by Salem (2019, this special issue) who convincingly demonstrates in this issue how the EU manages the strategic marriage of inclusive gender discourse to free trade strategies. In the context of economic growth and DCFTAs, an advisor to the European External Action Service usefully articulated this progressive discourse of social inclusion via equitable trade:

economic growth and political stability are only sustainable if the growth is inclusive. We have to ensure that the growth will be inclusive, that it will address the issues of women's empowerment and youth unemployment' (Alar Olljum, 
Advisor for North Africa, the Middle East, the Arabian Peninsula, Iran and Iraq for the European External Action Service quoted in Friends of Europe 2012).

This egalitarian EU discourse seeks to allay the fears of domestic civil society actors and organisations who have pointed to the potential social repercussions of DCFTAs and liberalisation agreements. For example, a wide range of trade unions within the region have increasingly adopted a gender perspective, emphasising that women constitute a large proportion of the informal work force, and that they may bear the brunt of trade liberalisation.

Crucially, however, the EU's discourse of inclusive interdependence has not diminished the activism of organised labour and other concerned citizens in the Arab Mediterranean regarding the impending impact of DCFTAs. Civil society groups in Tunisia, for example, have demanded that EU trade negotiations be accompanied by public consultation, and that all negotiating documents be disclosed (Gardner 2017). They have been particularly worried by the experience of Morocco's textile industry and have sought to guarantee protection for their own sectors in processes of liberalisation. Other groups have taken more radical stances. Alliances of organisations across Algeria, Tunisia, Egypt and Morocco have called for the end of free trade agreements which they argue - when coupled with debt - propagate the imperialist and neo-colonial domination of the region.

Specifically, the ATTAC/CADTM (Committee for the Abolition of Illegitimate Debt) Morocco (2015) has mobilised against the DCFTA and the threat posed to the Moroccan economy. In addition to calling for greater democracy and transparency surrounding trade negotiations, their opposition is explicitly framed in the language of neo-colonialism. The group has campaigned against the EU's neo-colonial 'partnership', under the slogan "No to colonial agreements, for the defence of people's sovereign right on their agricultural, food and environmental systems" (Climate and Capitalism, 2018). Their campaign works to highlight 
the economic impact of trade liberalisation with the EU, arguing that this will worsen inequalities between regions and classes, and intensify the commodification and dismantling of public services. Their campaign places particular focus on the intensification of the control of multinational corporations over agriculture and fishing; associated commodity speculation; and the generalisation of export-orientated agriculture and the fishing industry. Through these and other related movements there is an emergent programme of radical, anti-colonialist resistance and action in the Arab Mediterranean. This reflects ongoing concerns about the imperial legacies - and the continued relevance of Nkrumah and Fanon for contemporary social movements in the region in opposition to neo-colonial trade ties.

\section{Conclusion}

It is clear from the above discussion that the European Commission has articulated a Eurafrican imperial discourse relating to economic interdependence and complementarity within an amnestic approach to the Arab Mediterranean. Moreover, the EU's pursuit of DCFTAs can accurately be read in terms of Nicolaidis' (2015) concept of redirection. EU member states have subsumed their competing nationalist impulses within the project of European integration. Subsequently, the European project seeks to transpose, and impose, its trade norms onto its former colonies in the Arab Mediterranean, and beyond. It is important, however, to simultaneously re-engage the work of African luminaries who critiqued neo-colonialism as it initially arose. In particular, it is necessary to re-engage the works of Nkrumah (1965), Fanon (1961) and Touré (1962) in terms of analysing - and critiquing - Europe's recourse to a blend of trade negotiations and aid delivery in the pursuit of European commercial advantage. EU free trade vehicles, including the DCFTAs, perpetuate African countries' subordinate 
economic status - since meaningful strategies for economic diversification and industrialisation are foreclosed by premature liberalisation.

Moreover, as the empirical discussion of the likely impact of DCFTAs demonstrates, Europe's normative discourse stands in stark juxtaposition to the material impact of its trade policy. Whereas the European Commission insists that its pursuit of free trade is an opportunity for shared prosperity, the consequences of EU import flooding - combined with European protectionism embodied in the CAP - leaves little scope for genuine poverty reduction. On the contrary, the DCFTAs will exacerbate ill-being and insecurity. On the basis of self-interest alone, therefore, it would seem opportune for the EU to rethink its regressive DCFTA agenda in light of potential consequences for EU member states themselves vis-à-vis regional insecurity.

Crucially, local resistance to the DCFTA agenda is currently embodied by a myriad of civil society organisations in the Arab Mediterranean who seek to overturn regressive liberalisation agendas. Following the logic of Nkrumah's (1965) analysis of neo-colonialism, moreover, it would appear crucial that countries in the Arab Mediterranean should seek closer co-operation with sub-Saharan African states to develop their collective position within the AU. However, the extent to which a bi-continental Eurafrican free trade zone would disrupt or retrench neo-colonial trade relations is now the arena of debate. Only through a united AU position, combined with the vocal activism of civil society and trade unions, can genuine pressure for change to EU trade liberalisation policies be brought to bear. Mobilising a progressive discourse of resistance to neo-colonialism would appear a vital component of such pan-African strategies, in countering the Eurafrican mentalities of an amnestic Europe.

\section{References}

ACP-EU. 2000. Cotonou Partnership Agreement. Brussels: European Commission 
Borgen Project. 2016. Closing in on Food Insecurity in Morocco. $7^{\text {th }}$ October.

https://borgenproject.org/food-insecurity-in-morocco/

Cebeci, Müevver, and Tobias Schumacher. 2017. "The EU Constructions of the

Mediterranean (2003-2017)". MedReset Papers. Working Paper No. 3. April Rome: Istituto Affari Internazionali.

Chadwick, Vince. 2017. "What Does EU Development Policy Mean By 'Root Causes of Migration'?" DEVEX, $16^{\text {th }}$ November. https://www.devex.com/news/what-does-eudevelopment-policy-mean-by-root-causes-of-migration-91369

Chadwick, Vince. 2018. 'EU Eyes Africa Free-Trade Deal Amid Battle for Influence' DEVEX, 13tth September. https://www.devex.com/news/eu-eyes-africa-free-trade-deal-amidbattle-for-influence-93417

Chang, Ha-Joon. 2002. Kicking Away the Ladder. London: Anthem

Climate and Capitalism. 2018. Agadir Declaration. ATTAC: For Food Sovereignty, Against 'Free Trade' Agreements. 26 ${ }^{\text {th }}$ January. http://climateandcapitalism.com/2018/01/26/attacfor-food-sovereignty-against-free-trade-agreements26732/ 
Del Sarto, Raffaella.A. 2016. "Normative Empire Europe: The European Union, its Borderlands, and the “Arab Spring." Journal of Common Market Studies, 54 (2): 215-232. https://doi.org/10.1111/jcms.12282

Djafari, Nassir. 2018. "Tackling Trade and Migration" Development and Cooperation. $4^{\text {th }}$ April. https://www.dandc.eu/en/article/north-africa-eu-trade-policy-not-reducing-migration$\underline{\text { so-far-actually-adding-problem }}$

European Commission. 1993. "Euro-Maghreb Partnership". Press Release. Brussels: European Commission. http://europa.eu/rapid/press-release_IP-93-1038_en.htm

European Commission. 1996. Green Paper on the Relations between the European Union and the ACP Countries on the Eve of the 21st Century. Brussels: European Commission.

European Commission. 2005. EU Strategy for Africa: Towards a Euro-African Pact to Accelerate Africa's Development. Brussels: European Commission

European Commission. 2006. Making Trade Work for Development: Aid for Trade - A Selection of Case Studies from Around the World. Brussels: European Commission European Commission. 2007. Remarks in the Debate on the Future of the EuroMed Process. Brussels: European Commission. http://trade.ec.europa.eu/doclib/docs/2007/october/tradoc_136504.pdf

European Commission. 2018a. Euromed Statement by Commissioner Cecilia Malmstrom. Brussels: European Commission. 
European Commission. 2019a. Morocco-Trade-European Commission. Brussels: European Commission. $7^{\text {th }}$ May. http://ec.europa.eu/trade/policy/countries-andregions/countries/morocco/

European Commission. 2019b. Tunisia-Trade-European Commission. Brussels: European Commission. $7^{\text {th }}$ May. http://ec.europa.eu/trade/policy/countries-andregions/countries/tunisia/

Fanon, Frantz. (1961). 2001. The Wretched of the Earth. Reprint. London: Penguin Classics.

Friends of Europe (2012) Reform Growth in Arab-EU Trade.

https://www.friendsofeurope.org/sites/default/files/media/uploads/2014/10/FoE-Report-ArabEUTrade-2012-WEB.pdf

Galtung, Johan. 1973. The European Community: A Superpower in the Making. London: Allen \& Unwin

Gardner, Mike. 2017. "Free or Fair - EU trade with the Maghreb Region" Rural 21: The International Journal for Rural Development. $20^{\text {th }}$ November.

http://www.rural21.com/english/news/detail/article/free-or-fair-eu-trade-with-the-maghreb$\underline{\text { region- }-00002578 /}$

Gruhn, Isebill.V. 1976. “The Lomé Convention: Inching Towards Interdependence.” International 
Organization. 30(2): 241-62. https://doi.org/10.1017/\$0020818300018269

Hansen, Peo. and Stefan Jonsson. 2014. Eurafrica: The Untold History of European Integration and Colonialism. London: Bloomsbury Academic.

Hurt, Stephen. 2003. "Co-operation and Coercion? The Cotonou Agreement between the European Union and the ACP States and the End of the Lomé Convention.” Third World Quarterly, 24(1): 161-176. https://doi.org/10.1080/713701373

Gardner, David. 2017. "Tunisia: An Arab Anomaly, by Safwan M. Masri - A Review”. The Financial Times. 30 ${ }^{\text {th }}$ October. https://www.ft.com/content/789c8274-ba5a-11e7-8c12$\underline{5661783 e 5589}$

GPA and Solidar. 2013. Another Trade is Possible. Tunis: GPA.

http://www.solidar.org/IMG/pdf/solidar-gpf_wsf 2013 -

panel briefing_on trade no bio.pdf

International Labour Organisation. 2016. "Facing the Growing Unemployment Challenges in Africa" Press Release. January $20^{\text {th }}$. http://www.ilo.org/addisababa/mediacentre/pr/WCMS 444474/lang--en/index.html

Langan, Mark. 2012. "Normative Power Europe and the Moral Economy of ACP-EU Ties: A Conceptual Reorientation of Normative Power" New Political Economy, 17(3), pp.243-270. https://doi.org/10.1080/13563467.2011.562975 
Langan, Mark. 2015a. "Budget Support and Africa-European Union Relations: Free Market

Reform and Neo-Colonialism”, European Journal of International Relations, 21 (1), 101-12. https://doi.org/10.1177/1354066113516813

Langan Mark. 2015b. "The Moral Economy of EU Relations with North African States:

DCFTAs under the European Neighbourhood Policy". Third World Quarterly, 36(10), 1827-

1844. https://doi.org/10.1080/01436597.2015.1071660

Langan, Mark. 2017. Neo-Colonialism and the Poverty of 'Development' in Africa. New York: Palgrave.

Martin, Guy. 1982. "Africa and the Ideology of Eurafrica: Neo-Colonialism or PanAfricanism?" Journal of Modern African Studies, 20(2):221-238. https://doi.org/10.1017/S0022278X00024459

Nicolaïdis, Kalypso. 2015. 'Southern Barbarians? A Post-Colonial Critique of EUniversalism', in K. Nicolaïdis, B. Sébe and G. Maas (eds.), Echoes of Empire: Memory, Identity and Colonial Legacies. London: I.B. Tauris, pp. 283-303.

Morillas, Pol. and Eduard Soleri I Lecha. 2017. “The EU’s Framing of the Mediterranean (1990-2002): Building a Euro-Mediterranean Partnership” MedReset Papers. Working Paper No. 2. Rome: Istituto Affari Internazionali

Nkrumah, Kwame. 1965. Neo-colonialism: The Last Stage of Imperialism. London: Nelson. 
Nunn, Alex, and Sophia Price. 2004. "Managing Development: EU and African Relations

Through the Evolution of the Lomé and Cotonou Agreements" Historical Materialism, 12(4), pp. 203-230. https://doi.org/10.1163/1569206043505220

OECD. 2018. Unemployment Rates Available at:

https://data.oecd.org/unemp/unemployment-rate.html Accessed $1^{\text {st }}$ May 2018

Pace, Michelle. 2007. "The Construction of EU Normative Power” Journal of Common Market Studies, 45(5), pp.1041-1064. https://doi.org/10.1111/j.1468-5965.2007.00759.x

Pace, Michelle. and Roberto Roccu. 2019. "Introduction: Amnesiac Power Europe? Imperial Pasts in the EU's Approach to the Mediterranean”. Interventions, XXX

Pasture, Patrick. 2018. "The EC/EU Between the Art of Forgetting and the Palimpsest of Empire", European Review, 26(3): 545-581. http://doi.org/10.1017/S1062798718000224

Salem, Sara. 2019. "Revisiting Frantz Fanon: The EU and the Question of Postcolonial Agency in Egypt". Interventions, XXX

Segal, Aaron. 1964. “Africa Newly Divided?” Journal of Modern African Studies, 2(1): 73 90. https://doi.org/10.1017/S0022278X00003682

Stevens, Christopher and Jane Kennan. 2005. EU-ACP Economic Partnership Agreements: The Impact of 
Reciprocity. Brighton: Institute for Development Studies. May.

https://www.ids.ac.uk/files/CSEPARECBP2.pdf

Swearingen, Will.D. 1988. Moroccan Mirages: Agrarian Dreams and Deceptions, $1912-$ 1986. London: I. B. Tauris and Co. Ltd.

Touré, Sékou. 1962. “Africa's Future and the World”. Foreign Affairs, 41: 141-15.

DOI:10.2307/20029606

Thorpe, Benjamin, J. 2018. "EurAfrica: A Pan-European Vehicle for Central European

Colonialism (1929-1939).” European Review, 26(3): 503-

513.http://doi.org/10.1017/S1062798718000200

Zielonka, Jan. 2006. Europe as Empire: The Nature of the Enlarged European Union. Oxford: Oxford University Press. 